\title{
A multilevel analysis of perceived intergenerational mobility and welfare state preferences
}

\author{
Forthcoming in International Journal of Social Welfare
}

Alexi Gugushvili

Department of Social Policy and Intervention and Nuffield College, University of Oxford, UK

Key words: subjective intergenerational mobility, welfare state attitudes, education, healthcare, pensions, housing, Life in Transition Survey

Accepted for publication: 25 January 2018

Correspondence Author:

Alexi Gugushvili

Department of Social Policy and Intervention and Nuffield College

University of Oxford

Barnett House,

32 Wellington Square, Oxford OX1 2ER, United Kingdom

Tel: +44186580552

E-mail: alexi.gugushvili@spi.ox.ac.uk 


\begin{abstract}
Previous scholarship suggests that the effect of perceived intergenerational mobility on attitudes related to social justice, inequality, and redistribution is more salient than the effect of individuals' objective intergenerational mobility. However, virtually no studies have attempted to link individuals' perception of experiencing intergenerational mobility and their support for different welfare state programmes. In my study using nationally representative and comparative survey data for 33 Western European welfare democracies and post-socialist transition societies, I found that perceived intergenerational mobility is associated with support for certain welfare state programmes. Results from multilevel linear probability models indicate that subjectively downwardly mobile individuals are less likely to support education and healthcare expenditure and more likely to prefer targeted assistance of the poor, while subjectively upwardly mobile individuals oppose extra spending on housing and old-age pensions. The described associations are more vividly manifested in post-socialist societies than in the analysed Western European democracies.
\end{abstract}




\section{Introduction}

This study explored the association between perceived or subjective intergenerational mobility and attitudes towards welfare state programmes. Previous studies, using various data sets and research designs have investigated the consequences of intergenerational mobility in individuals' objective characteristics on support for redistribution. While some scholars' findings suggest that upward mobility is negatively associated with redistribution preferences (Alesina \& La Ferrara, 2005; Jaime-Castillo \& Mareques-Perales, 2014; Siedler \& Sonnenberg, 2012), others have found no, or even positive, associations between the two (Clark \& D'Angelo, 2010; Gugushvili, 2016a; Guillaud, 2013).

A reason for this inconsistency in findings may be that redistribution preferences are usually studied unidimensionally, without considering attitudes towards separate channels of redistribution via specific welfare state programmes. Distinct welfare schemes have different goals, beneficiaries, and administrative and financial structures and therefore the research on cumulative welfare preferences might conflate the negative and positive effects of intergenerational mobility on redistribution preferences. Existing studies reveal considerable variation in the effect of individual characteristics on distinct welfare state programmes such as pensions, housing, and social assistance (Busemeyer, Goerres, \& Weschle, 2009; Gugushvili, 2015b; Kitschelt \& Rehm, 2006). By the same token, intergenerational mobility experience may have different implications for attitudes regarding separate dimensions of the welfare state. Upwardly mobile individuals may not be against all forms of redistribution, as some of the existing findings suggest, while downwardly mobile individuals may support one policy over another (Clark \& D’Angelo, 2010; Gugushvili, 2014). 
This study aimed to contribute to the social welfare and social stratification literature by exploring the consequences of perceived intergenerational mobility. Unlike objective intergenerational mobility, which is often measured by the association between social background, on the one hand, and individuals' educational, occupational, or income attainment, on the other (Goldthorpe, 2013), subjective approaches to social mobility are based on respondents' perceptions of how well they have done in life compared with their parents (Segura, 1989). The recent findings provide some evidence that perceived intergenerational mobility exerts stronger effects on various political and economic attitudes than does objective occupational mobility (Gugushvili, 2016a,b; Turner, 1992). Inconsistencies between perceptions of mobility and objective mobility experiences are attributed to people's tendency to consider their own success in broader terms than educational or occupational attainment. Individuals generally think that positive relationships with family and friends and leisure activities are just as important as occupational mobility in determining success (Duru-Bellat \& Kieffer, 2008). The main thing that differentiates the intergenerational mobility concept of social scientists with that imagined by individuals is the pre-objectified social structure used by the former, while the latter view their relative positions in comparison with their parents from their own particular view of the social world (Merllié, 2008).

In addition to disentangling the links between perceived intergenerational mobility and support for separate welfare state programmes, this study was also motivated by the recent findings on cross-national differences in both the rates of intergenerational mobility (Bukodi, Paskov, \& Nolan, 2017; Gugushvili, 2015a, 2017a,b; Gugushvili et al., 2018; Jackson \& Evans, 2017) and in support of different welfare state programmes (Blekesaune \& Quadagno, 2003; 
Busemeyer et al., 2009; Gugushvili, 2015b) in Western European welfare democracies and postsocialist transition societies. One of the factors explaining why individuals within these nations are more likely to prefer specific welfare programmes might be their subjective perception of experiencing (or not experiencing) intergenerational mobility. Some scholars have noted a possible association between intergenerational mobility and specific areas of the welfare state (e.g. Clark \& D'Angelo, 2010), but to my knowledge the implications of perceived intergenerational mobility for specific welfare programmes have not been investigated in crossnational perspective. To empirically test the main research question of this study, I used comparative survey data for 33 European welfare democracies and post-socialist transition societies.

In the next section I outline theoretical considerations based on material self-interest and social-psychological foundations of support for welfare state programmes with corresponding hypotheses on the role of upward and downward intergenerational mobility for individuals' preferences. This is followed by a detailed description of the institutional context, research design, variables, and statistical tools employed. Bivariate and multivariate analysis in the results section suggest that support for certain welfare state programmes among both subjectively upward and subjectively downward mobile individuals is statistically different from the support of non-mobile individuals. The final section summarises the study and briefly outlines the implications of the findings.

\section{Theoretical considerations}

Material self-interest and perceived intergenerational mobility 
There are several theoretical mechanisms which can potentially explain why, intergenerationally, mobile individuals are more likely than non-mobile individuals to support or oppose certain welfare state programmes. Extensive research on welfare state attitudes convincingly demonstrates that material self-interest is one of the most important mechanisms affecting individuals' preferences (Baslevent \& Kirmanoglu, 2011; Mau, 2003; Naumann, 2014). This is evident in relation to specific welfare programmes. A pension system elicits stronger support from older persons because it targets people who reach a defined retirement threshold (Fernández, 2013). At the other end of an age-defined support for welfare state programmes is public spending on the educational system which mostly directs resources to youth and young adults, leading to support for greater investment among these groups (Busemeyer et al., 2009). Further, if we consider various groups in the socio-economic hierarchy, the strongest supporters of egalitarian redistributive measures such as social housing and targeted social assistance are the main beneficiaries of these policies - disadvantaged and deprived individuals (Pfeifer, 2009).

The main reason why we have to consider individuals' material self-interest while theorising about the links between perceived intergenerational mobility and support for welfare state programmes is that those who perceive themselves as being downwardly mobile are also more likely to be in social need than non-mobile or upwardly mobile individuals. Among other components of the welfare state, programmes directed at dealing with basic human needs such as shelter and food provisions might be prioritised by those who consider that they have done worse in life than their parents. On the other hand, individuals experiencing upward social mobility are likely to be in more advantaged socio-economic conditions than non-mobile and downwardly mobile individuals, and therefore they would require qualitatively different welfare state 
provisions. It is known that relatively better-off individuals are more likely to be enrolled in various educational institutions and to utilise publicly provided services (Bukodi, 2017; Vandycke, 2001). Hence, educational expenditure might be regressive in nature from the perspective of the disadvantaged individuals who believe that they are experiencing intergenerational downward mobility.

\section{Social-psychological foundations of support for welfare state programmes}

Even after accounting for individuals' current socio-economic conditions, intergenrationally mobile individuals might have extra reason to support or oppose specific welfare state programmes. The social-psychological foundations of beliefs about inequality are particularly important in this regard (Kaufman, 2009). Various recent studies in social psychology, social policy, and sociology suggest that perceived level of inequality of opportunity is associated with preferences for redistributive policies (Jaime-Castillo \& Mareques-Perales, 2014; Kim, Huh, Choi, \& Lee, 2017; Shariff, Wiwad, \& Aknin, 2016). The main mechanism underpinning this link is that when individuals perceive that everyone gets a fair chance to succeed in life, then redistributive policies should be limited because a talent- and effort-based meritocracy is an appropriate method of distributing resources (Alesina \& Giuliano, 2009; Kluegel \& Smith, 1986). If perception of intergenerational mobility is an important factor for welfare preferences, then it is likely that individuals' perceived mobility experience would play an equally important role in shaping their attitudes towards welfare state programmes (Steele, 2015).

An important social-psychological concept - the self-serving bias in causal attribution might be particularly relevant in explaining preferences for certain welfare state programmes 
among intergenrationally mobile individuals. Causal attribution refers to the process by which individuals form causal explanations for their own, as well as others' behaviours (Semin \& Zwier, 1997). The self-serving bias implies that individuals are more likely to attribute failures to factors that are beyond their control, or situational factors, and more likely to explain success by pointing to their own merits, abilities, and efforts, or dispositional factors (Mezulis, Abramson, Hyde, \& Hankin, 2004). The self-serving bias is associated with individuals' need to control their lives and the attribution to self of success and the attribution to external factors of failure is one of the aspects of these control attempts (Miller \& Ross, 1975).

I apply this well-established phenomenon in social psychology to perceived intergenerational mobility. We can assume that individuals start their adolescence and emerging adulthood with an initial set of attitudes, but over the years these preferences are affected, based on personal experiences of intergenerational mobility (Piketty, 1995) and on an associated perception of the role played by ascribed and attained factors in determining life chances (Schmidt, 2011). Upwardly mobile are likely to overestimate their individual contributions, such as effort and hard work, to success and failure, therefore perceiving existing inequalities as just (Gugushvili, 2016b; Kluegel \& Smith, 1986). Downwardly mobile individuals, on the other hand, are likely to assign a greater weight to external factors, such as social injustice, in shaping their life course, and are therefore more likely to think that society as a whole should be responsible for narrowing the existing gap between rich and poor (Gugushvili, 2016a; Newman, 1999).

Based on the outlined psychological mechanism of self-serving bias in causal attribution, upward mobility might be related to the perception that individual perseverance along with skills 
and talents are decisive factors for success in life. If the latter is the case, then welfare state programmes that intend to help individuals realise their full life potential should be supported by upwardly mobile individuals more than by those programmes that are designed to simply redistribute resources. The latter corresponds well with increasingly prevalent thinking in social policy literature regarding a developmental welfare state in which the emphasis is placed on 'preparing' individuals rather than 'repairing' them (Ahn \& Kim, 2015; Morel, Palier, \& Palme, 2012). This type of 'social investment' model of the welfare state puts a primary focus on individual responsibility and the resultant chances for upward intergenerational mobility (Pintelon, Cantillon, Van den Bosch, \& Whelan, 2013). Among various components of the welfare state, the major programme that can directly contribute to individuals' human capital formation is education (Schultz, 1961). Spending on education might be supported by upwardly mobile individuals who are more likely than non-mobile individuals to view equal access to human capital as an instrumental factor for positive life trajectories.

We can also speculate about the potential consequences of intergenerational downward mobility. Individuals who perceive that they have experienced downward mobility will be less likely to prioritise educational spending. This might be due to their self-serving bias in causal attribution which is triggered by adverse mobility experience. Downwardly mobile individuals are more likely to believe in structural explanations of success and failure rather than in longterm solutions through human capital formation. As was mentioned above, public spending in education may attract less support among the downwardly mobile because they do not expect to directly benefit as they are more likely to be out of the life stage in which individuals are typically enrolled in educational institutions. Welfare state programmes receiving more support 
from downwardly mobile individuals are likely to be spending on social housing, poverty assistance, and old-age provisions. This is the case because all of these programmes are designed to alleviate the socio-economic disadvantages of their beneficiaries. As for another important component of the welfare state - healthcare - this programme primarily addresses general existential risks and individuals' positions on the socio-economic ladder and their perceived intergenerational mobility should be less relevant in explaining support for this area of the welfare state (Kitschelt \& Rehm, 2006).

\section{Institutional legacy}

Based on previous research on the macro-level mechanisms of welfare state support (see Blekesaune \& Quadagno, 2013), it is also likely that countries' historical context moderates the effect of perceived intergenerational mobility on individuals' support for welfare state programmes. Most importantly, the legacy of socialism in Central and Eastern Europe has been shown to exert a long-lasting effect on post-socialist economic and political attitudes (PopEleches \& Tucker, 2014). It has been argued that in a number of post-socialist countries crony capitalism has replaced the previous socialist egalitarian policies (Smith, 2010). The limited role of the state in addressing social hardship could facilitate the prevalence of individualistic explanations among subjectively mobile individuals (Bucca, 2016), which might be reflected in their welfare state preferences. For instance, upwardly mobile individuals in post-socialist societies might be in favour of extra spending on the educational system. One of the explanations for this is the higher returns to tertiary education in post-socialist countries as compared with European welfare democracies (Brunello, Crivellaro, \& Rocco, 2010). Furthermore, 
intergenerationally downwardly mobile individuals in post-socialist countries might have stronger preferences for extra spending on poverty alleviation than those in Western welfare democracies. A main reason for this could be that downward mobility in post-socialist transition societies is more closely linked to material deprivation than in Western welfare democracies in which individuals are likely to be protected by an adequate social safety net (Figari, Matsaganis, \& Sutherland, 2013).

\section{Hypotheses}

Based on material self-interest and social-psychological mechanisms and historical legacies of socialism, the hypotheses to be tested in this article are the following: Hypothesis 1: Perceived intergenerational upward mobility positively associates with support for welfare programmes which enhance human capital, such as education, and negatively associates with primarily needsbased and redistributive welfare state programmes, such as pensions, assisting the poor, and social housing; Hypothesis 2: Perceived intergenerational downward mobility positively associates with primarily needs-based and redistributive welfare state programmes, such as pensions, assisting the poor, and social housing, and negatively associates with support for welfare programmes which enhance human capital, such as education; Hypothesis 3: The effect of perceived intergenerational mobility on attitudes towards welfare state programmes is stronger in post-socialist societies than it is in other Western welfare democracies. 


\section{Data and variables}

To test the links between perceived intergenerational mobility and welfare state preferences, I used data from the Life in Transition Survey (LITS) which was conducted by the European Bank for Reconstruction and Development (EBRD) in 2010. LITS contains representative samples of the adult populations derived from a two-stage sampling method that used census enumeration areas as primary sampling units and households as secondary sampling units. The survey provides data for the five Western European societies of France, Germany, Italy, Sweden, and the United Kingdom, while the pool of post-socialist countries is much larger and includes the following 28 transition societies: Albania, Armenia, Azerbaijan, Belarus, Bosnia and Herzegovina, Bulgaria, Croatia, Czech Republic, Estonia, Georgia, Hungary, Kazakhstan, Kosovo, Kyrgyzstan, Latvia, Lithuania, Macedonia, Moldova, Montenegro, Poland, Romania, Russia, Serbia, Slovakia, Slovenia, Tajikistan, Ukraine, and Uzbekistan. Based on the existing research on intergenerational mobility which shows that individuals reach a stage of 'maturity' in their socio-economic status only around their mid-30s (Gugushvili, Bukodi, \& Goldthorpe, 2017), I excluded individuals aged 34 or less from the analysed sample. After list-wise deleting observations with missing data, 21,895 individuals remained for multivariate analysis.

\section{Dependent variables}

To understand the role of perceived intergenerational mobility for specific welfare state preferences, I used the survey item that asks respondents the following question: 'In your opinion, which of these fields should be the first (the second) priority for extra government spending?' The welfare state programmes mentioned in the answer choices were education 
[23.6\% and $21.9 \%$ of responses for the first and the second priority in the pooled sample], healthcare [39.8\% and 33.8\%], housing [6.7\% and 10.1\%], pensions [16.1\% and $19.5 \%$ ], and 'assisting the poor' [ $13.9 \%$ and $14.7 \%$ ]. Of the respondents, $4.1 \%$ and $4.5 \%$ did not provide an answer on their first and second priorities on extra government spending and therefore were excluded from the analysis. The main concern with the survey question used is that it might not explicitly describe general attitudes towards the welfare state programmes but rather reflect preferences regarding additional spending for specific welfare policies. However, because this study's main goal was to investigate welfare preferences between intergenrationally mobile and non-mobile groups within countries, different levels of welfare state development across societies could be tolerated (Gugushvili, 2015b).

Table 1 shows how responses on welfare state preferences were distributed in Western European and post-socialist societies. The comparison across these two sets of countries suggests that extra spending in education was more preferred in Western Europe than in post-socialist societies, while pensions was a more frequently named option in post-socialist societies. The latter can be explained by the salient role old-age pensions played in post-socialist transition in many Central and Eastern European economies (e.g. Guardiancich, 2013; Gugushvili, 2009). In both sets of countries, the highest support for extra government spending went to healthcare, with more than $70 \%$ of respondents choosing healthcare as the first or the second priority for government investment; education was the second most supported welfare area. More than onethird of respondents believed that pensions should be the priority for government spending, and a slightly lower share of respondents prioritised assisting the poor. It is also surprising that poverty was not more prioritised in post-socialist societies than in Western European countries which are 
generally characterised by lower deprivation levels (Alam et al., 2005; Gugushvili, 2011; Whelan, Nolan, \& Maître, 2014).

\section{TABLE 1 ABOUT HERE}

\section{Perceived intergenerational mobility}

LITS asked respondents whether they agree or disagree with the following statement: 'I have done better in life than my parents.' From a 5-point Likert scale respondents could choose from 'strongly disagree' to 'strongly agree'. Respondents were also instructed to compare their parents' position to their own when the former were at the same age as the respondents at the time of the interview. Of the respondents, $3.6 \%$ did not provide an answer to this question, while the valid answers were transformed into following five categorical variables: strongly disagree $=$ strongly downwardly mobile [6.0\% in the pooled sample], disagree $=$ downwardly mobile [19.2\%], neither disagree nor agree $=$ non-mobile $[24.5 \%]$, agree $=$ upwardly mobile [38.3\%], and strongly agree $=$ strongly upwardly mobile $[12.0 \%]$.

The described indicator of perceived intergenerational mobility does not necessarily imply intergenerational mobility in terms of educational, occupational, or income mobility. First, individuals' tend to consider their own success in life in comparison with their parents' in broader terms than a mechanical movement on intergenerational socio-economic ladder (DuruBellat \& Kieffer, 2008). This is why in multivariate analysis I accounted for a wide array of socio-demographic variables such as marital status, type of settlement, individuals' own and their parents' socio-economic status. Second, perceived intergenerational mobility can also reflect the structural upgrade of the economy, for example collective mobility which refers to the overall improvement of socio-economic conditions in a society rather than an individuals' own 
experience of intergenerational mobility (Marshall, 1996). To mitigate the latter problem, I adjusted the empirical analysis by including a country-level development indicator in multilevel statistical models.

The right-hand side of Table 1 depicts the structure of perceived intergenerational mobility in the considered Western European and post-socialistic societies. The descriptive statistics suggest that differences between these two sets of countries were not very large. Nonetheless, individuals in the pooled sample of Germany, France, Italy, Sweden, and the United Kingdom were 4.0 percentage points less likely to report experiencing downward intergenerational mobility than were individuals in post-socialist societies. In turn, in the former set of countries respondents were 5.6 percentage points less likely to report experiencing stability in intergenerational mobility than were those in the Western European democracies. The latter finding might be related to the fundamental economic, political, and social changes experienced by residents of these countries since the beginning of the 1990s (Gugushvili, 2015a).

\section{Other independent variables}

In addition to basic socio-demographic variables such as gender (male=1), age of respondents (with age squared), and marital status (married=1), I also employed a number of variables that were expected to be associated with welfare state preferences (see Furåker \& Blomsterberg, 2003; Gelissen, 2000; Pfeifer, 2009; Van Oorschot \& Meuleman, 2012; Wong, Wan, \& Law, 2009). Type of settlement was accounted for with a dummy variable for urban and rural areas, with metropolitan residency serving as the reference category. The highest level of completed education is based on the 1997 version of International Standard Classification of Education 
[ISCED] which varies from ISCED 0 [pre-primary education] to ISCED 6 [second stage of tertiary education]. For socio-economic status, respondents were asked to place their households on a 10-step ladder with 1 [bottom of the scale] representing a country's poorest $10 \%$ of people, and 10 [top of the scale] representing the richest $10 \%$. To account for short-term change in subjective socio-economic status, I used a LITS question that asked respondents to declare their 2006 household incomes using the 10-step ladder. I subtracted position in time $\mathrm{t}_{\text {[2010] }}$ with a

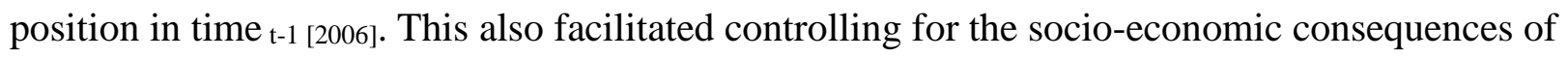
the 2008-2010 economic crisis (Tóth, 2008).

To control for employment-related effects, I created dummy variables for different types of labour market positions. For those individuals who worked for income during the 12 months prior to their interview, four occupational categories were assigned. In LITS, individuals' occupations were classified with the 1958 version of the International Standard Classification of Occupations [ISCO] which I grouped in the following four categories - ISCO: 0-2 [professional, technical, clerical, and related workers; administrative, executive, and managerial workers]; ISCO: 3 and 9 [sales workers; service, sport, and recreation workers]; ISCO: 4-5 [farmers, fishermen, hunters, miners, quarrymen, and related workers], and ISCO: 7-8 [craftsmen, production-process workers, and labourers]. Those individuals who were not employed but were looking for a job or were interested in finding one were classified as unemployed. Retired consisted of a group of pensioners who were out of the labour market at the time of interview; individuals with other labour market status served as the reference category.

Lastly, to account for the effect of social origins, the models controlled for years of parental education, which was the only variable available in LITS about individuals' social 
background. Since this variable had a high proportion of missing observations [22.0\%], I created a categorical variable with 'missing' as a category used in the regressions. The reference category was $<=5$ years of parental education. 6-11 years of education is roughly equal to secondary education, while $12=>$ years of education could be considered as postsecondary/tertiary education. I used the dominance approach, which means that if parents had different levels of educational attainment, the higher of the two was assigned to the respondents' parents (Erikson, 1984). The descriptive statistics of all independent variables in the pooled samples for Western welfare democracies and post-socialist transition societies are presented in Table A1 in the Appendix.

\section{Country-level variables}

To assess the importance of institutional legacies, I derived a dummy variable for the countries that had been a part of the socialist block (see the list of these societies in the above description of the dataset). To account for countries' economic development, I selected the most commonly used measure in empirical research - gross domestic product (GDP) per capita based on purchasing power parity (ppp). Data were in constant 2011 international dollars and were derived from the World Bank's World Development Indicators (WDI) database. The descriptive statistics for GDP ppp per capita indicates that Western welfare democracies (mean: 38,528 USD) and post-socialist countries (mean: 14,884 USD) differed in their level of economic development.

\section{Methods}


The empirical analysis begins with a description of the bivariate associations between perceived intergenerational mobility and support for welfare state programmes, without accounting for respondents' socio-demographic and socio-economic characteristics. For the multivariate analysis, I separately constructed five binary dependent variables that take a value of 1 if respondents selected education, healthcare, housing, pensions, or 'assisting the poor' as the first or second priority for extra government spending. For each welfare state programme, I devised a multilevel linear probability regression model which allowed accounting for economic development and socialist legacy at the country-level, and adjusted estimates for a heterogeneous error term distribution by nesting individuals in 33 countries. Coefficients from multilevel linear probability regressions come close to the average marginal effects of multilevel logistic models (Angrist \& Pischke, 2009).

For understanding the effects of institutional legacies and testing Hypothesis 3, I included in multilevel linear regressions cross-level interactions between perceived intergenerational mobility and a dummy variable for post-socialist countries. Because a substantive interpretation of the effects of interaction terms in regression models is often deceptive (Brambor, Clark, \& Golder, 2006), in the pooled analysis I concentrated only on the substantive and statistical significance of the presented cross-level interactions. This was followed by disaggregated analysis of Western welfare democracies and post-socialist transition societies. The latter results are presented in graphs which show point estimates with corresponding confidence intervals from five separate models (Kastellec \& Leoni, 2007). To check the robustness of the findings, I created a categorical variable for attitudes towards different welfare programmes and fitted 
multilevel multinomial logistic regressions. The results derived using this approach were very similar to those discussed in the main analysis using multilevel linear probability models.

\section{Results}

\section{Bivariate analysis}

Figure 1 depicts bivariate associations between perceived intergenerational mobility and preferences for extra spending on education, healthcare, housing, pensions, and assisting the poor, in the pooled sample of countries. The major differences across subjectively mobile groups in their welfare state preferences were largely in line with the stated hypothesis. Regarding the first priority in Figure 1.1, upwardly mobile individuals were found to have stronger preferences for extra spending on education [25.6\% for strongly upwardly mobile vs. $16.6 \%$ for strongly downwardly mobile], while the share of downwardly mobile individuals who named pensions and assisting the poor [18.0 and $17.5 \%$, respectively, for strongly downward mobile] was higher than the same share in all other mobility groups [13.7 and $11.8 \%$, respectively, for strongly upwardly mobile individuals]. There were no salient differences in terms of the links between perceived intergenerational mobility and preferences for healthcare and housing. Both of these welfare state programmes were equally supported by people with perceptions of upward mobility, downward mobility, and unchanged intergenerational status. The described variances in associations between perceived intergenerational mobility and welfare state preferences were still present, but they were less pronounced when I considered the second priority for extra government spending. Figure 1.2 shows that strongly downwardly mobile individuals had the lowest support for healthcare, $28.0 \%$, while for non-mobile group of individuals this support was 
7.2 percentage points higher. In addition, for the second priority, extra spending on housing was more likely to be preferred by the strongly downwardly mobile group [12.7\%] than by upwardly $[10.2 \%]$ and strongly upwardly $[9.2 \%]$ mobile individuals.

\section{FIGURE 1 ABOUT HERE}

After looking at the bivariate links between intergenerational mobility and support for separate welfare state programmes, we can also discuss the same associations separately for Western European welfare democracies and post-socialist transition societies (see Figure A1 in Appendix). The general associations between perceived intergenerational mobility and preferred areas of extra government spending observed for the pooled sample were similar, but there were a few interesting deviations. Across all mobility groups, extra spending on education was prioritised in Western European societies. For instance, among strongly upwardly mobile individuals in these countries, $31.0 \%$ of individuals chose education as the first priority, while the corresponding share in post-socialist countries was only $19.0 \%$. It was also noticeable that among downwardly mobile groups in Western Europe, support for housing as the area of extra government spending was stronger than in post-socialist societies. Extra spending on healthcare was equally preferred in both sets of countries, but upwardly mobile groups exhibited a stronger preference for this welfare state programme only in the Western European sample. The described bivariate analysis served as the preliminary test of Hypotheses 1 and 2 and provided tentative evidence on the significant links between intergenerational mobility and support for welfare state programmes.

\section{Multilevel multivariate analysis}


In this section I tested whether the observed bivariate associations were also salient when accounting for individuals' socio-demographic and socio-economic characteristics and the specific effects related to countries where they resided. Table 2 depicts the point estimates for covariates of welfare state support that were derived from multilevel linear probability models. First, I briefly describe the effects of other individual-level independent variables on welfare preferences, before proceeding to the associations of perceived intergenerational mobility with the dependent variables.

In line with the previous scholarship, age had negative and positive links, respectively, with preferences for extra spending on education and pensions, but in both cases the effect also appeared to be curvilinear. Married individuals were more likely to prefer extra government spending on education and healthcare, but were less likely to support spending on pensions and on the poor. Rural residents were less concerned with housing but preferred spending directed toward poverty alleviation. Respondents' education and their subjective socio-economic status were both positively associated with extra spending on education and were negatively associated with extra spending on pensions and the poor. The unemployed, when compared with individuals in the reference category, were significantly more likely to prefer extra government spending on the poor and housing, but they were also less likely to support spending on healthcare and pensions. Those having white-collar jobs represented the only occupational category that was in favour of spending on education. Farmers did not support healthcare spending, while blue-collar workers and those employed in unskilled service occupations were very similar to each other with respect to their welfare preferences - supporting housing but opposing extra government spending on the poor. Retired expectedly were in favour of pensions. As for social origins, 
parental education did not exhibit any systemic and significant associations with welfare state spending preferences.

\section{TABLE 2 ABOUT HERE}

Let us return to the main research question of this article: How is perceived intergenerational mobility associated with support for welfare state programmes? The point estimates from multilevel linear probability models partially confirmed the stated hypotheses. In Models 1, 3, 5, 7, and 9, regression coefficients showed the mobility effects in the pooled sample of Western mature democracies and post-socialist societies, while Models 2, 4, 6, 8, and 10 also included interactions between subjective mobility and the socialist legacy. In line with Hypothesis 2, in both of these specifications, strong downward mobility was negatively associated with preferences for extra spending on education $[-2.8 \%$ and $-9.2 \%, \mathrm{p}<0.1]$ when compared with non-mobile individuals. Strongly downwardly mobile individuals had a $3.7 \%$ $(\mathrm{p}<0.01)$ lower likelihood of preferring extra spending on healthcare, but when this association was adjusted for the socialist legacy in Model 4, the scale of the effect increased to $9.5 \%$ $(\mathrm{p}<0.01)$. The interaction term between strong downward mobility and the dummy variable for socialist legacy was also positive and statistically significant, suggesting that the main effect was primarily observed in the Western welfare democracies.

Spending on housing was not preferred by survey respondents who reported experiencing upward mobility $[-1.4 \%, \mathrm{p}<0.1]$ and strong upward mobility $[-1.6 \%, \mathrm{p}<0.05]$ in Model 5 , but after adjusting for the institutional context in Model 6, this effects applied only in post-socialist countries. On the other hand, subjective downward mobility was positively related to support for housing spending only in Western mature democracies [strongly downward: $6.5 \%, \mathrm{p}<0.1$, 
downward: $2.0 \%, \mathrm{p}<0.01]$. As regards pensions, in line with Hypothesis 1, both upwardly and strongly upwardly mobile individuals were $1.7 \%(\mathrm{p}<0.05)$ and $5.0 \%(\mathrm{p}<0.01)$ less likely than non-mobile individuals to favour further spending on pensions, and this effect was largely maintained in Model 8. Furthermore, the interaction term and the regression coefficient for strong downward mobility also suggested that perceived mobility was associated with support for pensions mainly in the Western welfare democracies. Individuals who believed that they were experiencing downward and strongly downward intergenerational mobility were significantly more likely to support additional spending on the poor, but this association was observed mainly in Model 9 (5.6\%, p<0.01 and 3.3\%, p<0.01, respectively). The latter effect was strongest among other associations that we have observed for perceived intergenerational mobility in the analysis of the pooled sample. Lastly, the two considered contextual variables were positively associated with support for healthcare (GDP per capita) and pensions (socialist legacy), on the one hand, and were negatively associated with support for poverty assistance (GDP per capita) and education (socialist legacy), on the other.

In Figure 2, which is based on identical multilevel linear probability regressions as presented in Table 2, the pool of Western European welfare democracies and post-socialist transition societies was split by fitting separate multilevel linear probability regressions in these two sets of countries. The reference category for each type of perceived mobility experience was the group of non-mobile individuals. The presented regression coefficients were statistically significant when their $95 \%$ confidence intervals did not cross the vertical zero reference line. The comparison between Figures 2.1 and 2.2 was in line with Hypothesis 3, confirming that the results observed in the pooled Models 1,3, 5, 7, and 9 in Table 2 were more vividly manifest 
among individuals living in post-socialist societies. One of the reasons the effects of subjective mobility were less pronounced in the Western welfare democracies was the smaller size of their pooled sample with the corresponding larger standard errors when compared with the pooled sample of post-socialist societies.

The results confirmed that in both sets of countries, strongly downwardly mobile individuals opposed further spending on healthcare. The scale of this effect was $-8.8 \%(\mathrm{p}<0.01)$ and $-3.0 \%(\mathrm{p}<0.05)$ in Western European democracies and post-socialist societies, respectively. Strongly downwardly mobile individuals in the pooled sample of Germany, France, Sweden, Italy, and the United Kingdom were, respectively, 6.0\% $(\mathrm{p}<0.1)$ and $4.7 \%(\mathrm{p}<0.01)$ more likely to prefer extra spending on housing and pensions. In addition, in post-socialist societies, both downward $(3.6 \%, \mathrm{p}<0.01)$ and strongly downward $(5.7 \%, \mathrm{p}<0.01)$ groups were significantly more likely than non-mobile individuals to favour further spending on the poor.

\section{FIGURE 2 ABOUT HERE}

When it comes to the effect of perceived upward mobility on individuals' welfare state preferences, mobile individuals were statistically different from non-mobile individuals only in post-socialist societies. Healthcare was the only welfare state programme for which upward intergenerational mobility did not make a difference. Upwardly mobile individuals supported further spending in education. This effect was $1.8 \%$ for upwardly mobile individuals at the $10 \%$ significance level. Further, spending on pensions was a less preferred option among upwardly mobile groups, the point estimates taking the values of $-5.4(\mathrm{p}<0.01)$ for strongly upwardly and $-1.8 \%(0.1)$ for upwardly mobile individuals. The effect of perceived upward mobility was also manifest in post-socialist societies in opposing spending on publicly provided housing. The scale 
of the association was about $2 \%(\mathrm{p}<0.05)$. The described results largely confirmed Hypotheses 1 to 3 , suggesting that there are statistically significant links between perceived intergenerational mobility and preferred welfare state programmes and that the legacy of socialism affects this association.

\section{Discussion and conclusions}

The main goal of this study was to identify the association between perceived intergenerational mobility and support for various welfare state programmes. My theoretical reasoning implied that, based on considerations shaped by material self-interest, individuals who perceive themselves as being intergenerationally upwardly and downwardly mobile would have different needs and expectations from certain welfare state programmes than those who consider themselves as being intergenerationally non-mobile. The latter is the case because intergenerational mobility is usually, although not always, related to changes in individuals' socio-economic status. More importantly, based on social-psychological theories of beliefs about equality of opportunity and the role of situational and dispositional factors in the intergenerational mobility process, individuals' perceptions of intergenerational upward mobility might be positively related to their beliefs that talent and perseverance are decisive factors for success. For the latter reason, they are more likely to support welfare state programmes which are conducive to human capital formation. On the other hand, individuals who perceive themselves to be intergenerationally downwardly mobile are also more likely to believe in a structural explanation of success and failure in life and therefore they would support welfare 
state programmes with a more redistributive nature, such as spending on housing, pensions, and social assistance for the poor.

Using bivariate and multilevel multivariate analysis to test the formulated hypotheses, I found that perceived intergenerational mobility was a statistically significant predictor of support for certain welfare state programmes. The analysis of the pooled sample of 33 European welfare democracies and post-socialist transition societies revealed that, when asked about their preferences for extra government spending, individuals who perceived themselves as being downwardly mobile on average preferred spending on poverty alleviation and pensions, while they opposed extra spending on education and healthcare. For the latter welfare programme, the existing studies suggest that socio-economic conditions are positively associated with access and utilisation of healthcare services (Balabanova, McKee, Pomerleau, Rose, \& Haerpfer, 2004; Phelan, Link, \& Tehranifar, 2010), which might make this area of social provision appear regressive and, consequently, less supported by downwardly rather than upwardly mobile individuals.

On the other hand, those who perceived themselves being intergenerationally upwardly mobile opposed extra spending on housing and pensions. The magnitude of the effect of downward mobility was as high as that observed for most socio-demographic and socioeconomic variables such as gender and labour market status. When the effects of perceived intergenerational mobility were disaggregated by two sets of countries, we saw that upward mobility exerted its effect only in post-socialist transition societies. However, unlike the latter set of countries, in European welfare democracies strong downward mobility was associated with support for housing and pensions and it was also related to more stringent opposition to spending 
on healthcare. The finding that perceived intergenerational mobility was a more important predictor of individuals' preferences in post-socialist countries than in European welfare democracies is in line with previous results on the effects of perceived intergenerational mobility on popular explanations of poverty (Gugushvili, 2016b).

It is also important to discuss a number of caveats of the described analysis. Probably the most salient problem for the study of attitudinal consequences of mobility is the direction of causality in the findings. The proposed Hypotheses 1 and 2 argue that the subjective perception of intergenerational mobility causes specific attitudes about welfare state programmes; however, the data and methodology do not allow for the exclusion of the possibility of reverse causation. Upwardly mobile individuals might have had similar attitudes even before developing their perception of intergenerational mobility. In fact, individualistic dispositions and redistribution preferences could contribute to their life trajectories. Another limitation of the employed analytical strategy is that LITS does not allow for accounting for important components of the welfare state such as unemployment benefits and assistance to families with children and people with disabilities (van Oorschot, 2006). Furthermore, unlike objective intergenerational mobility, variables such as educational and occupational attainment, both the dependent and the main independent variables, are subjective in nature. This inevitably raises concerns about the crosscultural comparability of the results. Lastly, the welfare programmes that were analysed in the study cannot be single-handedly described in terms of the meritocratic and redistributive properties of groups. For instance, public old-age pension schemes vary across countries in terms of the degree to which they redistribute resources from the rich to the poor. 
Bearing in mind the limitations of this study, it is still worthwhile to consider what the potential implications of the derived findings are for comparative social welfare research. First, future studies should consider various factors that affect individuals' perceptions of experiencing intergenerational mobility. Relationships between perceived intergenerational mobility and objective mobility measures are generally, but not always, positive. Empirical evidence suggests that perceived mobility is correlated with a broader set of factors such as macro-level development in the countries where individuals reside. For instance, the comparative analysis of 30 nations using International Social Survey Programme data, which, along with objective intergenerational mobility variables, asked respondents to compare their own occupational status with the status of their fathers, indicated that objective intergenerational mobility has an important effect on perceptions of intergenerational mobility, along with two other factors intergenerational educational gains, and change in GDP per capita from the respondents' childhood to the date of the interview (Kelley \& Kelley, 2009). Further research needs to be done to understand how individuals' perceptions of intergenerational mobility change over time and how they are affected by major events such as regime change and economic recession.

Perceived intergenerational mobility might also have significant consequences for welfare state development and reforms, as individuals' perceptions are one of the most important aspects that affect the democratic political process and consequently shape the welfare state's goals, beneficiaries, and administrative and financial structures (Breznau, 2016; Petersen, Sznycer, Cosmides, \& Tooby, 2012). If certain societies, due to various exogenous shocks such as regime change or a major economic crisis, experience a surge in perceptions of downward mobility, this might lead to greater support for welfare state programmes that aim to satisfy basic 
human needs, such as shelter and food provisions, at the expense of more elaborate welfare provisions for healthcare and education. On the other hand, due to long-term prosperity in European welfare democracies and overall improvement of socio-economic conditions, the majority of individuals might feel intergenerationally upwardly mobile, thus giving less consideration to those socio-economic groups who have been left behind, disregarding corresponding welfare programmes and the idea of the 'European Social Model' (Bilbao-Ubillos, 2016).

\section{References}

Ahn, S.-H., \& Kim, S.-W. (2015). Social investment, social service and the economic performance of welfare states. International Journal of Social Welfare, 24(2), 109-119. https://doi.org/10.1111/ijsw.12094

Alam, A., Murthi, M., Yemtsov, R., Murrugarra, E., Dudwick, N., Hamilton, E., \& Tiongson, E. (2005). Growth, poverty, and inequality: Eastern Europe and the former Soviet Union. Washington, DC: World Bank. Retrieved from http://siteresources.worldbank.org/INTECA/Resources/complete-eca-poverty.pdf

Alesina, A. F., \& Giuliano, P. (2009). Preferences for redistribution. National Bureau of Economic Research.

Alesina, A., \& La Ferrara, E. (2005). Preferences for redistribution in the land of opportunities. Journal of Public Economics, 89(5-6), 897-931. https://doi.org/10.1016/j.jpubeco.2004.05.009

Angrist, J. D., \& Pischke, J.-S. (2009). Mostly Harmless Econometrics: An Empiricist's Companion. Princeton: Princeton University Press.

Balabanova, D., McKee, M., Pomerleau, J., Rose, R., \& Haerpfer, C. (2004). Health Service Utilization in the Former Soviet Union: Evidence from Eight Countries. HSR: Health Services Research, 36(9), 1927-1950.

Baslevent, C., \& Kirmanoglu, H. (2011). Discerning self-interested behaviour in attitudes 
towards welfare state responsibilities across Europe. International Journal of Social Welfare, 20(4), 344-352. https://doi.org/10.1111/j.1468-2397.2010.00751.x

Bilbao-Ubillos, J. (2016). Is there still such a thing as the "European social model"?

International Journal of Social Welfare, 25(2), 110-125. https://doi.org/10.1111/ijsw.12177

Blekesaune, M., \& Quadagno, J. (2003). Public Attitudes toward Welfare State Policies.

European Sociological Review, 19(5), 415-427. Retrieved from

http://www.ingentaconnect.com/content/oup/eursoj/2003/00000019/00000005/art00415

Blekesaune, M., \& Quadagno, J. (2013). Public Attitudes Analysis of State Policies: Welfare

State Controversies. European Sociological Review, 19(5), 415-427.

Brambor, T., Clark, W. R., \& Golder, M. (2006). Understanding Interaction Models: Improving Empirical Analyses. Political Analysis, 14(1), 63-82. https://doi.org/10.1093/pan/mpi014

Breznau, N. (2016). Positive Returns and Equilibrium: Simultaneous Feedback Between Public Opinion and Social Policy. Policy Studies Journal. https://doi.org/10.1111/psj.12171

Brunello, G., Crivellaro, E., \& Rocco, L. (2010). Lost in Transition? The Returns to Education Acquired under Communism 15 years after the Fall of the Berlin Wall. Bonn.

Bucca, M. (2016). Merit and Blame in Unequal Societies: Explaining Latin Americans' Beliefs about Wealth and Poverty. Research in Social Stratification and Mobility, 44, 98-112. https://doi.org/10.1016/j.rssm.2016.02.005

Bukodi, E. (2017). Cumulative Inequalities over the Life-Course: Life-long Learning and Social Mobility in Britain. Journal of Social Policy, 46(2), 367-404. https://doi.org/10.1017/S0047279416000635

Bukodi, E., Paskov, M., \& Nolan, B. (2017). Intergenerational class mobility in Europe: A new account and an old story (No. INET Oxford Working Paper nos. 2017-3). Oxford.

Busemeyer, M. R., Goerres, A., \& Weschle, S. (2009). Attitudes towards redistributive spending in an era of demographic ageing: The rival pressures from age and income in 14 OECD countries. Journal of European Social Policy, 19(3), 195-212. https://doi.org/10.1177/0958928709104736

Clark, A., \& D’Angelo, E. (2010). Upward Social Mobility, Well-being and Political Preferences: Evidence from the BHPS. Working Paper, Nr. 338. Ancona: Universita' 
Politecnica delle Marche.

Duru-Bellat, M., \& Kieffer, A. (2008). Objective/subjective: The two facets of social mobility. Sociologie Du Travail, 50(0), e1-e18. https://doi.org/10.1016/j.soctra.2008.07.001

EBRD (2010). Life in Transition Survey. European Bank for Reconstuction and Development, London.

Erikson, R. (1984). Social Class of Men, Women and Families. Sociology, 18(4), 500-514. https://doi.org/10.1177/0038038584018004003

Fernández, J. J. (2013). Broad Reciprocity, Elderly Poverty, and the Retiree/Nonretiree Cleavage in the Demand for Public Retirement Income Support. Social Problems, 60(2), 255-280. https://doi.org/10.1525/sp.2013.60.2.255

Figari, F., Matsaganis, M., \& Sutherland, H. (2013). Are European social safety nets tight enough? Coverage and adequacy of Minimum Income schemes in 14 EU countries. International Journal of Social Welfare, 22(1), 3-14. https://doi.org/10.1111/j.14682397.2012.00885.x

Furåker, B., \& Blomsterberg, M. (2003). Attitudes towards the unemployed. An analysis of Swedish survey data. International Journal of Social Welfare, 12(3), 193-203. https://doi.org/10.1111/1468-2397.t01-1-00005

Gelissen, J. (2000). Popular support for institutionalised solidarity: a comparison between European welfare states. International Journal of Social Welfare, 9, 285-300.

Goldthorpe, J. H. (2013). Understanding - and Misunderstanding - Social Mobility in Britain: The Entry of the Economists, the Confusion of Politicians and the Limits of Educational Policy. Journal of Social Policy, 42(3), 431-450. https://doi.org/10.1017/S004727941300024X

Guardiancich, I. (2013). Pension Reforms in Central, Eastern and Southeastern Europe: From Post-Socialist Transition to the Global Financial Crisis. London: Routledge.

Gugushvili, A. (2009). Political economy of old-age pension reforms in Georgia. Caucasian Review of International Affairs, 3(4), 371-386.

Gugushvili, A. (2011). Material Deprivation, Social Class and Life Course in the Balkans, Eastern Europe and Central Asia. Studies of Transition States and Societies, 3(1), 39-54. Gugushvili, A. (2014). Trends, Covariates and Consequences of Intergenerational Social 
Mobility in Post-Socialist Societies. Political and Social Sciences. European University Institute, Florence.

Gugushvili, A. (2015a). Economic Liberalization and Intergenerational Mobility in Occupational Status. Comparative Sociology, 14(6), 790-820. https://doi.org/10.1163/1569133012341368

Gugushvili, A. (2015b). Self-interest, Perceptions of Transition and Welfare Preferences in the New Eastern Europe and the South Caucasus. Europe-Asia Studies, 67(5), 718-746. https://doi.org/10.1080/09668136.2015.1045451

Gugushvili, A. (2016a). Intergenerational objective and subjective mobility and attitudes towards income differences: evidence from transition societies. Journal of International and Comparative Social Policy, 32(3), 199-219. https://doi.org/10.1080/21699763.2016.1206482

Gugushvili, A. (2016b). Intergenerational Social Mobility and Popular Explanations of Poverty: A Comparative Perspective. Social Justice Research, 29(4), 402-428. https://doi.org/10.1007/s11211-016-0275-9

Gugushvili, A. (2017a). Change or continuity? Intergenerational social mobility and postcommunist transition. Research in Social Stratification and Mobility, 52, 59-71. https://doi.org/10.1016/j.rssm.2017.10.004

Gugushvili, A. (2017b). Political democracy, economic liberalization, and macro-sociological models of intergenerational mobility. Social Science Research, 66, 58-81. https://doi.org/10.1016/j.ssresearch.2017.06.003

Gugushvili, A., Bukodi, E., \& Goldthorpe, J. H. (2017). The Direct Effect of Social Origins on Social Mobility Chances: "Glass Floors" and "Glass Ceilings" in Britain. European Sociological Review, 33(2), 305-316. https://doi.org/10.1093/esr/jcx043

Gugushvili, A., McKee, M., Murphy, M., Azarova, A., Irdam, D., Doniec, K., \& King, L. (2018). Intergenerational Mobility in Relative Educational Attainment and Health-Related Behaviours. Social Indicators Research. https://doi.org/10.1007/s11205-017-1834-7 Guillaud, E. (2013). Preferences for redistribution: an empirical analysis over 33 countries. The Journal of Economic Inequality, 11(1), 57-78. https://doi.org/10.1007/s10888-011-9205-0 
Jackson, M., \& Evans, G. (2017). Rebuilding Walls: Market Transition and Social Mobility in the Post-Socialist Societies of Europe. Sociological Science, 4, 54-79. https://doi.org/10.15195/v4.a3

Jaime-Castillo, A. M., \& Mareques-Perales, I. (2014). Beliefs about Social Fluidity and Preferences for Social Policies. Journal of Social Policy, 43(3), 615-633. https://doi.org/10.1017/S0047279414000221

Kastellec, J. P., \& Leoni, E. L. (2007). Using Graphs Instead of Tables in Political Science. Perspectives on Politics, 5(4), 755-771. https://doi.org/10.1017/S1537592707072209

Kaufman, R. R. (2009). Inequality and Redistribution: Some Continuing Puzzles. PS: Political Science \& Politics, 42(4), 657-660. https://doi.org/10.1017/S1049096509990060

Kelley, S. M. C., \& Kelley, C. G. E. (2009). Subjective social mobility: Data from 30 nations. In M. Haller, R. Jowell, \& T. Smith (Eds.), Charting the Globe: The International Social Survey Programme 1984-2009. London: Routledge.

Kim, H., Huh, S., Choi, S., \& Lee, Y. (2017). Perceptions of inequality and attitudes towards redistribution in four East Asian welfare states. International Journal of Social Welfare. https://doi.org/10.1111/ijsw.12266

Kitschelt, H., \& Rehm, P. (2006). New social risk and political preferences. In K. Armingeon \& G. Bonoli (Eds.), The politics of post-industrial welfare states. Adapting post-war social policies to new social risks. London: Routledge.

Kluegel, J. R., \& Smith, E. R. (1986). Beliefs About Inequality: Americans' Views of What Is and What Ought to Be. New York: Aldine Transaction.

Marshall, G. (1996). Was Communism Good for Social Justice?: A Comparative Analysis of the Two Germanies. The British Journal of Sociology, 47(3), 397-420. https://doi.org/10.2307/591359

Mau, S. (2003). The Moral Economy of Welfare States: Britain and Germany Compared. London: Routledge.

Merllié, D. (2008). How to compare "subjective" and "objective" mobility. Sociologie Du Travail, 50(0), e50-e65. https://doi.org/10.1016/j.soctra.2008.07.004

Mezulis, A. H., Abramson, L. Y., Hyde, J. S., \& Hankin, B. L. (2004). Is There a Universal 
Positivity Bias in Attributions? A Meta-Analytic Review of Individual, Developmental, and Cultural Differences in the Self-Serving Attributional Bias. Psychological Bulletin, 130(5), 711-747. https://doi.org/10.1037/0033-2909.130.5.711

Miller, D. T., \& Ross, M. (1975). Self-serving biases in the attribution of causality: Fact or fiction? Psychological Bulletin, 82(2), 213-225. https://doi.org/10.1037/h0076486

Morel, N., Palier, B., \& Palme, J. (2012). Towards a Social Investment Welfare State? Ideas, Policies and Challenges. Bristol: Policy Press.

Naumann, E. (2014). Increasing conflict in times of retrenchment? Attitudes towards healthcare provision in Europe between 1996 and 2002. International Journal of Social Welfare, 23(3), 276-286. https://doi.org/10.1111/ijsw.12067

Newman, K. S. (1999). Falling from Grace: Downward Mobility in the Age of Affluence. Berkeley: University of California Press.

Petersen, M. B., Sznycer, D., Cosmides, L., \& Tooby, J. (2012). Who Deserves Help? Evolutionary Psychology, Social Emotions, and Public Opinion about Welfare. Political Psychology, 33(3), 395-418. https://doi.org/10.1111/j.1467-9221.2012.00883.x

Pfeifer, M. (2009). Public Opinion on State Responsibility for Minimum Income Protection: A Comparison of 14 European Countries. Acta Sociologica, 52(2), 117-134. https://doi.org/10.1177/0001699309104000

Phelan, J. C., Link, B. G., \& Tehranifar, P. (2010). Social Conditions as Fundamental Causes of Health Inequalities: Theory, Evidence, and Policy Implications. Journal of Health and Social Behavior, 51(1 Suppl), S28-S40. https://doi.org/10.1177/0022146510383498

Pintelon, O., Cantillon, B., Van den Bosch, K., \& Whelan, C. T. (2013). The social stratification of social risks: The relevance of class for social investment strategies. Journal of European Social Policy, 23(1), 52-67. https://doi.org/10.1177/0958928712463156

Pop-Eleches, G., \& Tucker, J. A. (2014). Communist socialization and post-communist economic and political attitudes. Electoral Studies, 33(0), 77-89. https://doi.org/http://dx.doi.org/10.1016/j.electstud.2013.06.008

Schmidt, A. (2011). The experience of social mobility and the formation of attitudes toward redistribution. GK SOCLIFE Working Papers Series. Cologne: Cologne Graduate School in 
Management, Economics and Social Sciences, University of Cologne.

Schultz, T. W. (1961). Investment in Human Capital. The American Economic Review, 51(1-17). https://doi.org/10.2307/1238690

Segura, D. A. (1989). Chicana and Mexican Immigrant Women at Work: The Impact of Class, Race, and Gender on Occupational Mobility. Gender and Society, 3(1), 37-52. https://doi.org/10.1177/089124389003001003

Semin, G. R., \& Zwier, S. M. (1997). Social Cognition. In J. W. Berry, M. H. Segall, \& C. Kagitçibasi (Eds.), Handbook of Cross-Cultural Psychology - Volume 3: Social Behavior and Applications (Vol. Volume 3:, pp. 51-75). Boston: Allyn and Bacon.

Shariff, A. F., Wiwad, D., \& Aknin, L. B. (2016). Income Mobility Breeds Tolerance for Income Inequality: Cross-National and Experimental Evidence. Perspectives on Psychological Science, 11(3), 373-380. https://doi.org/10.1177/1745691616635596

Siedler, T., \& Sonnenberg, B. (2012). Intergenerational earnings mobility and preferences for redistribution. Bonn, Germany: Institute for the Study of Labor (IZA).

Smith, M. L. (2010). Perceived corruption, distributive justice, and the legitimacy of the system of social stratification in the Czech Republic. Communist and Post-Communist Studies, 43(4), 439-451. https://doi.org/10.1016/j.postcomstud.2010.10.005

Steele, L. G. (2015). Income Inequality, Equal Opportunity, and Attitudes About Redistribution. Social Science Quarterly, 96(2), 444-464. https://doi.org/10.1111/ssqu.12145

Tóth, I. G. (2008). The Demand for Redistribution: A Test on Hungarian Data. Czech Sociological Review, 44(6), 1063-1087.

Turner, F. C. (1992). Social Mobility and Political Attitudes in Comparative Perspective. In F. C. Turner (Ed.), Social Mobility and Political Attitudes: Comparative Perspectives (pp. 1-20). New Brunswick, NJ: Transaction Publishers.

van Oorschot, W. (2006). Making the difference in social Europe: deservingness perceptions among citizens of European welfare states. Journal of European Social Policy, 16(1), 2342. https://doi.org/10.1177/0958928706059829

Van Oorschot, W., \& Meuleman, B. (2012). Welfarism and the multidimensionality of welfare state legitimacy: Evidence from The Netherlands, 2006. International Journal of Social 
Welfare, 21(1), 79-93. https://doi.org/10.1111/j.1468-2397.2010.00779.x

Vandycke, N. (2001). Access to education for the poor in Europe and Central Asia: preliminary evidence and policy implications (Vol. World Bank). Washington, D.C.: The World Bank.

Whelan, C. T., Nolan, B., \& Maître, B. (2014). Multidimensional poverty measurement in Europe: An application of the adjusted headcount approach. Journal of European Social Policy, 24(2), 183-197. https://doi.org/10.1177/0958928713517914

Wong, T. K., Wan, S. P., \& Law, K. W. (2009). Welfare attitudes and social class: the case of Hong Kong in comparative perspective. International Journal of Social Welfare, 18(2), 142-152. https://doi.org/10.1111/j.1468-2397.2008.00576.x 
Figure 1. Bivariate associations between subjective social mobility and preferences on extra governmental spending on various welfare state programmes.
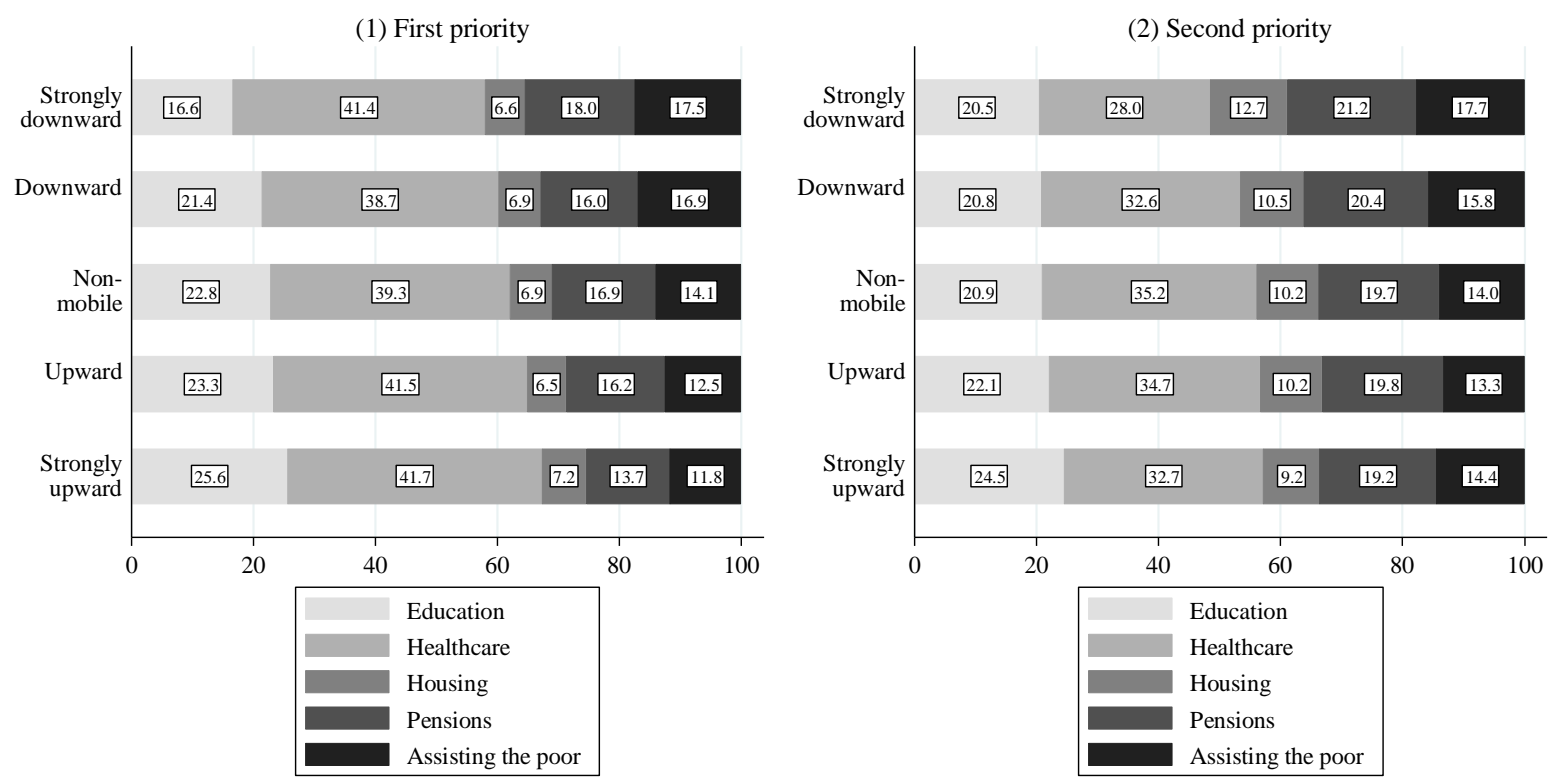

Notes: Weights applied.

Source: Author's calculations based on data from LITS (EBRD, 2010). 
Figure 2. Subjective social mobility and preferences on extra government spending on various welfare state programmes in Western European and post-socialist societies.

Point estimates from multilevel linear probability models.

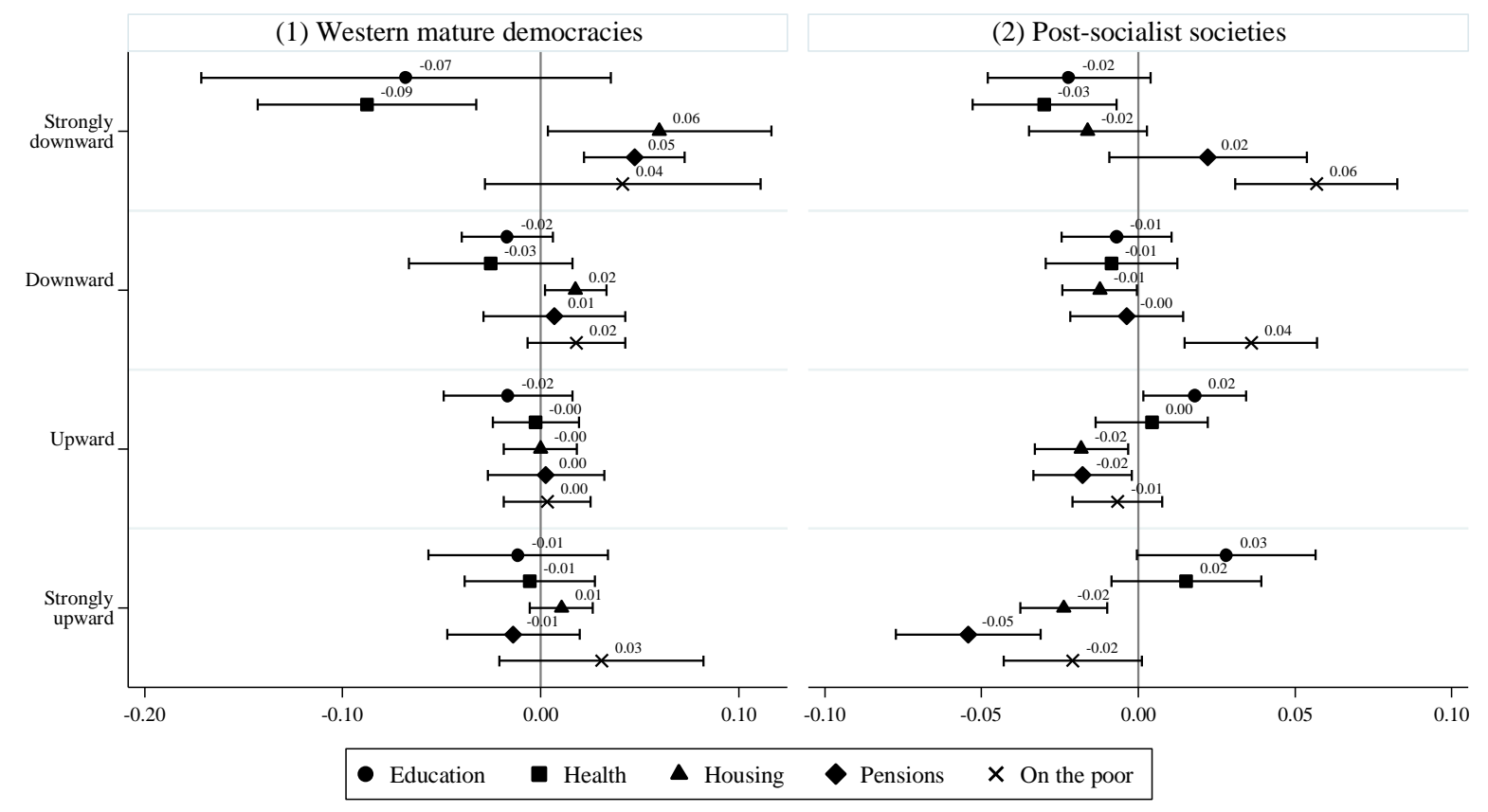

Notes: Bars represent $95 \%$ confidence intervals. For each set of countries five separate multilevel linear probability models are estimated. Models control for all variables shown in Table 2, weights applied.

Source: Author's calculations based on data from LITS (EBRD, 2010). 
Table 1. Distribution of dependent and independent variables in western European and post-socialist societies.

\begin{tabular}{|c|c|c|c|c|c|c|c|}
\hline & \multicolumn{4}{|c|}{ Dependent variable } & & \multicolumn{2}{|c|}{ Independent variable } \\
\hline & \multicolumn{4}{|c|}{$\begin{array}{l}\text { "Which of these fields should be priority for extra government } \\
\text { spending?" }\end{array}$} & & \multirow{2}{*}{\multicolumn{2}{|c|}{$\begin{array}{l}\text { Subjective intergenerational } \\
\text { mobility }\end{array}$}} \\
\hline & \multicolumn{2}{|c|}{ First priority } & \multicolumn{2}{|c|}{ Second priority } & & & \\
\hline & $\begin{array}{c}\text { Western } \\
\text { welfare } \\
\text { democracies }\end{array}$ & $\begin{array}{l}\text { Post-socialist } \\
\text { transition } \\
\text { societies }\end{array}$ & $\begin{array}{c}\text { Western } \\
\text { welfare } \\
\text { democracies }\end{array}$ & $\begin{array}{l}\text { Post-socialist } \\
\text { transition } \\
\text { societies }\end{array}$ & & $\begin{array}{c}\text { Western } \\
\text { welfare } \\
\text { democracies }\end{array}$ & $\begin{array}{c}\text { Post-socialist } \\
\text { transition } \\
\text { societies }\end{array}$ \\
\hline Education & 26.4 & 19.1 & 24.3 & 18.8 & Strongly downward & 4.4 & 7.4 \\
\hline Healthcare & 39.3 & 41.7 & 35.2 & 32.4 & Downward & 18.7 & 19.7 \\
\hline Housing & 5.6 & 8.8 & 9.0 & 11.7 & Non-mobile & 27.4 & 21.8 \\
\hline Pensions & 14.3 & 18.0 & 17.5 & 22.4 & Upward & 36.5 & 40.0 \\
\hline Assisting the poor & 15.3 & 12.5 & 13.9 & 14.7 & Strongly upward & 13.0 & 11.1 \\
\hline In total & 100.0 & 100.0 & 100.0 & 100.0 & In total & 100.0 & 100.0 \\
\hline
\end{tabular}

Note: Weights applied.

Source: Author's calculations based on data from LITS (EBRD, 2010). 
Table 2. Perceived intergenerational mobility and preferences on extra government spending on various welfare programmes.

Point estimates from multilevel linear probability models.

\begin{tabular}{|c|c|c|c|c|c|c|c|c|c|c|}
\hline & \multicolumn{2}{|c|}{ Education } & \multicolumn{2}{|c|}{ Healthcare } & \multicolumn{2}{|c|}{ Housing } & \multicolumn{2}{|c|}{ Pensions } & \multicolumn{2}{|c|}{ On the poor } \\
\hline & Model 1 & Model 2 & Model 3 & Model 4 & Model 5 & Model 6 & Model 7 & Model 8 & Model 9 & Model 10 \\
\hline Intercept & $\begin{array}{l}0.708 * * * \\
(0.080)\end{array}$ & $\begin{array}{l}0.721 * * * \\
(0.080)\end{array}$ & $\begin{array}{l}0.632 * * * \\
(0.066)\end{array}$ & $\begin{array}{l}0.641 * * * \\
(0.064)\end{array}$ & $\begin{array}{l}0.281 * * * \\
(0.070)\end{array}$ & $\begin{array}{l}0.263 * * * \\
(0.066)\end{array}$ & $\begin{array}{r}-0.186^{*} \\
(0.101)\end{array}$ & $\begin{array}{r}-0.192 * \\
(0.102)\end{array}$ & $\begin{array}{l}0.627 * * * \\
(0.015)\end{array}$ & $\begin{array}{l}0.619 \text { *** } \\
(0.077)\end{array}$ \\
\hline \multicolumn{11}{|l|}{ Subjective mobility } \\
\hline Strongly downward & $\begin{array}{r}-0.028^{*} \\
(0.015)\end{array}$ & $\begin{array}{r}-0.092 * \\
(0.048)\end{array}$ & $\begin{array}{c}-0.037 * * * \\
(0.013)\end{array}$ & $\begin{array}{c}-0.095 * * * \\
(0.029)\end{array}$ & $\begin{array}{r}-0.006 \\
(0.011)\end{array}$ & $\begin{array}{r}0.065^{*} \\
(0.034)\end{array}$ & $\begin{array}{c}0.025 \\
(0.017)\end{array}$ & $\begin{array}{l}0.065^{* * *} \\
(0.013)\end{array}$ & $\begin{array}{l}0.056^{* * * *} \\
(0.014)\end{array}$ & $\begin{array}{c}0.048 \\
(0.038)\end{array}$ \\
\hline Downward & $\begin{array}{c}-0.008 \\
(0.009)\end{array}$ & $\begin{array}{c}-0.022 \\
(0.015)\end{array}$ & $\begin{array}{c}0.012 \\
(0.011)\end{array}$ & $\begin{array}{c}-0.031 \\
(0.022)\end{array}$ & $\begin{array}{c}-0.006 \\
(0.006)\end{array}$ & $\begin{array}{l}0.020 * * * \\
(0.007)\end{array}$ & $\begin{array}{c}-0.003 \\
(0.010)\end{array}$ & $\begin{array}{c}0.012 \\
(0.021)\end{array}$ & $\begin{array}{l}0.033 * * * \\
(0.011)\end{array}$ & $\begin{array}{r}0.022 * \\
(0.013)\end{array}$ \\
\hline Upward & $\begin{array}{c}0.012 \\
(0.009)\end{array}$ & $\begin{array}{c}-0.006 \\
(0.017)\end{array}$ & $\begin{array}{c}0.003 \\
(0.009)\end{array}$ & $\begin{array}{c}0.002 \\
(0.010)\end{array}$ & $\begin{array}{r}-0.014^{*} \\
(0.008)\end{array}$ & $\begin{array}{c}0.001 \\
(0.011)\end{array}$ & $\begin{array}{c}-0.017 * * \\
(0.008)\end{array}$ & $\begin{array}{c}-0.015 \\
(0.016)\end{array}$ & $\begin{array}{c}-0.005 \\
(0.008)\end{array}$ & $\begin{array}{c}0.003 \\
(0.012)\end{array}$ \\
\hline Strongly upward & $\begin{array}{c}0.022 \\
(0.015)\end{array}$ & $\begin{array}{c}0.010 \\
(0.025)\end{array}$ & $\begin{array}{c}0.011 \\
(0.012)\end{array}$ & $\begin{array}{c}-0.000 \\
(0.014)\end{array}$ & $\begin{array}{c}-0.016 * * \\
(0.008)\end{array}$ & $\begin{array}{c}0.010 \\
(0.011)\end{array}$ & $\begin{array}{c}-0.050 * * * \\
(0.011)\end{array}$ & $\begin{array}{c}-0.043 * * * \\
(0.013)\end{array}$ & $\begin{array}{c}-0.009 \\
(0.013)\end{array}$ & $\begin{array}{c}0.030 \\
(0.027)\end{array}$ \\
\hline \multicolumn{11}{|l|}{ Other independent variables } \\
\hline Males & $\begin{array}{c}-0.003 \\
(0.009)\end{array}$ & $\begin{array}{c}-0.003 \\
(0.009)\end{array}$ & $\begin{array}{c}-0.031 * * * \\
(0.007)\end{array}$ & $\begin{array}{c}-0.031 * * * \\
(0.007)\end{array}$ & $\begin{array}{c}-0.001 \\
(0.004)\end{array}$ & $\begin{array}{c}-0.001 \\
(0.004)\end{array}$ & $\begin{array}{l}0.016 \\
(0.011)\end{array}$ & $\begin{array}{c}-0.016 \\
(0.010)\end{array}$ & $\begin{array}{c}0.013 * \\
(0.008)\end{array}$ & $\begin{array}{l}0.013^{*} \\
(0.008)\end{array}$ \\
\hline Age & $\begin{array}{c}-0.015 * * * \\
(0.002)\end{array}$ & $\begin{array}{l}-0.015 * * * \\
(0.002)\end{array}$ & $\begin{array}{c}-0.000 \\
(0.002)\end{array}$ & $\begin{array}{r}-0.000 \\
(0.002)\end{array}$ & $\begin{array}{c}0.003^{*} \\
(0.002)\end{array}$ & $\begin{array}{r}-0.003^{*} \\
(0.002)\end{array}$ & $\begin{array}{l}0.017 * * * \\
(0.003)\end{array}$ & $\begin{array}{l}0.017 * * * \\
(0.003)\end{array}$ & $\begin{array}{r}-0.002 \\
(0.002)\end{array}$ & $\begin{array}{c}-0.002 \\
(0.002)\end{array}$ \\
\hline Age squared & $\begin{array}{l}0.010 * * * \\
(0.001)\end{array}$ & $\begin{array}{l}0.010 * * * \\
(0.001)\end{array}$ & $\begin{array}{c}0.000 \\
(0.001)\end{array}$ & $\begin{array}{c}0.000 \\
(0.001)\end{array}$ & $\begin{array}{c}0.001 \\
(0.001)\end{array}$ & $\begin{array}{c}0.001 \\
(0.001)\end{array}$ & $\begin{array}{c}-0.010 * * * \\
(0.002)\end{array}$ & $\begin{array}{c}-0.010 * * * \\
(0.002)\end{array}$ & $\begin{array}{c}0.001 \\
(0.002)\end{array}$ & $\begin{array}{c}0.001 \\
(0.002)\end{array}$ \\
\hline Married & $\begin{array}{l}0.049 * * * \\
(0.009)\end{array}$ & $\begin{array}{l}0.049 * * * \\
(0.009)\end{array}$ & $\begin{array}{l}0.024 * * * \\
(0.007)\end{array}$ & $\begin{array}{l}0.023^{* * *} \\
(0.007)\end{array}$ & $\begin{array}{c}0.009 \\
(0.006)\end{array}$ & $\begin{array}{c}-0.009 \\
(0.006)\end{array}$ & $\begin{array}{l}-0.042^{* * *} \\
(0.010)\end{array}$ & $\begin{array}{l}-0.042 * * * \\
(0.010)\end{array}$ & $\begin{array}{l}-0.027 * * * \\
(0.006)\end{array}$ & $\begin{array}{l}-0.027^{* * *} \\
(0.006)\end{array}$ \\
\hline \multicolumn{11}{|l|}{ Residency } \\
\hline Urban settlement & $\begin{array}{c}0.025 \\
(0.018)\end{array}$ & $\begin{array}{c}0.025 \\
(0.018)\end{array}$ & $\begin{array}{c}0.004 \\
(0.018)\end{array}$ & $\begin{array}{c}0.004 \\
(0.018)\end{array}$ & $\begin{array}{c}-0.023 \\
(0.014)\end{array}$ & $\begin{array}{c}-0.023 \\
(0.014)\end{array}$ & $\begin{array}{c}-0.020 \\
(0.018)\end{array}$ & $\begin{array}{c}-0.020 \\
(0.018)\end{array}$ & $\begin{array}{c}0.011 \\
(0.015)\end{array}$ & $\begin{array}{c}0.011 \\
(0.015)\end{array}$ \\
\hline Rural settlement & $\begin{array}{c}0.011 \\
(0.018)\end{array}$ & $\begin{array}{c}0.011 \\
(0.018)\end{array}$ & $\begin{array}{c}-0.016 \\
(0.015)\end{array}$ & $\begin{array}{c}-0.016 \\
(0.015)\end{array}$ & $\begin{array}{c}-0.035^{* *} \\
(0.014)\end{array}$ & $\begin{array}{c}-0.035 * * \\
(0.014)\end{array}$ & $\begin{array}{c}-0.019 \\
(0.017)\end{array}$ & $\begin{array}{c}-0.020 \\
(0.017)\end{array}$ & $\begin{array}{l}0.041 * * * \\
(0.016)\end{array}$ & $\begin{array}{l}0.041 * * * \\
(0.016)\end{array}$ \\
\hline \multicolumn{11}{|l|}{ Socio-economic variables } \\
\hline Respondents' education & $\begin{array}{l}0.048 * * * \\
(0.006)\end{array}$ & $\begin{array}{l}0.048 * * * \\
(0.006)\end{array}$ & $\begin{array}{c}-0.002 \\
(0.003)\end{array}$ & $\begin{array}{r}-0.002 \\
(0.003)\end{array}$ & $\begin{array}{c}-0.003 * * \\
(0.002)\end{array}$ & $\begin{array}{c}-0.003 * * \\
(0.002)\end{array}$ & $\begin{array}{c}-0.034 * * * \\
(0.005)\end{array}$ & $\begin{array}{c}-0.034 * * * \\
(0.005)\end{array}$ & $\begin{array}{l}-0.021 * * * \\
(0.004)\end{array}$ & $\begin{array}{l}-0.021 * * * \\
(0.004)\end{array}$ \\
\hline Socioeconomic ladder & $\begin{array}{l}0.017 * * * \\
(0.003)\end{array}$ & $\begin{array}{l}0.016 * * * \\
(0.003)\end{array}$ & $\begin{array}{c}0.002 \\
(0.003)\end{array}$ & $\begin{array}{c}0.002 \\
(0.003)\end{array}$ & $\begin{array}{c}-0.002 \\
(0.002)\end{array}$ & $\begin{array}{c}-0.002 \\
(0.002)\end{array}$ & $\begin{array}{c}-0.012 * * * \\
(0.002)\end{array}$ & $\begin{array}{c}-0.012 * * * \\
(0.002)\end{array}$ & $\begin{array}{c}-0.013 * * * \\
(0.003)\end{array}$ & $\begin{array}{l}-0.013 * * * \\
(0.003)\end{array}$ \\
\hline Mobility in ladder, 2006-2010 & 0.002 & 0.002 & 0.001 & 0.001 & 0.001 & 0.001 & -0.001 & -0.001 & -0.000 & -0.000 \\
\hline
\end{tabular}




\begin{tabular}{|c|c|c|c|c|c|c|c|c|c|c|}
\hline & $(0.003)$ & $(0.003)$ & $(0.004)$ & $(0.004)$ & $(0.002)$ & $(0.002)$ & $(0.003)$ & $(0.003)$ & $(0.003)$ & $(0.003)$ \\
\hline \multicolumn{11}{|l|}{ Labour market variables } \\
\hline White collar occupation & $\begin{array}{l}0.050 * * * \\
(0.017)\end{array}$ & $\begin{array}{l}0.050 * * * \\
(0.017)\end{array}$ & $\begin{array}{c}-0.012 \\
(0.011)\end{array}$ & $\begin{array}{c}-0.012 \\
(0.011)\end{array}$ & $\begin{array}{c}0.011 \\
(0.009)\end{array}$ & $\begin{array}{c}0.011 \\
(0.009)\end{array}$ & $\begin{array}{c}-0.020 \\
(0.014)\end{array}$ & $\begin{array}{c}-0.020 \\
(0.014)\end{array}$ & $\begin{array}{c}-0.055^{* * * *} \\
(0.015)\end{array}$ & $\begin{array}{l}-0.055^{* * *} \\
(0.015)\end{array}$ \\
\hline Blue collar occupation & $\begin{array}{c}0.001 \\
(0.015)\end{array}$ & $\begin{array}{c}-0.000 \\
(0.015)\end{array}$ & $\begin{array}{c}-0.011 \\
(0.011)\end{array}$ & $\begin{array}{c}-0.011 \\
(0.011)\end{array}$ & $\begin{array}{l}0.035^{* * * *} \\
(0.009)\end{array}$ & $\begin{array}{l}0.035^{* * * *} \\
(0.009)\end{array}$ & $\begin{array}{c}-0.037 * * * \\
(0.013)\end{array}$ & $\begin{array}{c}-0.037 * * * \\
(0.013)\end{array}$ & $\begin{array}{c}-0.030 * * \\
(0.013)\end{array}$ & $\begin{array}{c}-0.030 * * \\
(0.013)\end{array}$ \\
\hline Farmers & $\begin{array}{c}-0.016 \\
(0.034)\end{array}$ & $\begin{array}{c}-0.016 \\
(0.034)\end{array}$ & $\begin{array}{c}-0.067 * * * \\
(0.018)\end{array}$ & $\begin{array}{c}-0.067 * * * \\
(0.019)\end{array}$ & $\begin{array}{c}-0.013 \\
(0.015)\end{array}$ & $\begin{array}{c}-0.013 \\
(0.015)\end{array}$ & $\begin{array}{c}-0.027 \\
(0.019)\end{array}$ & $\begin{array}{c}-0.027 \\
(0.019)\end{array}$ & $\begin{array}{c}0.024 \\
(0.027)\end{array}$ & $\begin{array}{c}0.024 \\
(0.027)\end{array}$ \\
\hline Unskilled service occupation & $\begin{array}{c}0.005 \\
(0.020)\end{array}$ & $\begin{array}{c}0.005 \\
(0.020)\end{array}$ & $\begin{array}{c}-0.022 \\
(0.018)\end{array}$ & $\begin{array}{c}-0.022 \\
(0.018)\end{array}$ & $\begin{array}{l}0.032 * * \\
(0.015)\end{array}$ & $\begin{array}{l}0.032 * * \\
(0.015)\end{array}$ & $\begin{array}{c}-0.023 \\
(0.018)\end{array}$ & $\begin{array}{c}-0.022 \\
(0.018)\end{array}$ & $\begin{array}{r}-0.030 * \\
(0.017)\end{array}$ & $\begin{array}{r}-0.030 * \\
(0.017)\end{array}$ \\
\hline Unemployed & $\begin{array}{c}0.003 \\
(0.012)\end{array}$ & $\begin{array}{c}0.003 \\
(0.012)\end{array}$ & $\begin{array}{c}-0.064 * * * \\
(0.013)\end{array}$ & $\begin{array}{c}-0.064 * * * \\
(0.013)\end{array}$ & $\begin{array}{c}0.022 * \\
(0.012)\end{array}$ & $\begin{array}{r}0.022 * \\
(0.012)\end{array}$ & $\begin{array}{c}-0.029 * * \\
(0.012)\end{array}$ & $\begin{array}{c}-0.029 * * \\
(0.012)\end{array}$ & $\begin{array}{l}0.061 * * * \\
(0.016)\end{array}$ & $\begin{array}{l}0.061 * * * \\
(0.016)\end{array}$ \\
\hline Retired & $\begin{array}{c}-0.010 \\
(0.013)\end{array}$ & $\begin{array}{c}-0.010 \\
(0.013)\end{array}$ & $\begin{array}{c}-0.006 \\
(0.013)\end{array}$ & $\begin{array}{c}-0.007 \\
(0.013)\end{array}$ & $\begin{array}{c}-0.014 \\
(0.011)\end{array}$ & $\begin{array}{c}-0.014 \\
(0.011)\end{array}$ & $\begin{array}{l}0.113 * * * \\
(0.016)\end{array}$ & $\begin{array}{l}0.114 * * * \\
(0.016)\end{array}$ & $\begin{array}{l}-0.066 * * * \\
(0.012)\end{array}$ & $\begin{array}{l}-0.067 * * * \\
(0.012)\end{array}$ \\
\hline \multicolumn{11}{|l|}{ Social origin } \\
\hline Parental education: 6-11 years & $\begin{array}{c}0.016 \\
(0.010)\end{array}$ & $\begin{array}{c}0.016 \\
(0.010)\end{array}$ & $\begin{array}{c}0.006 \\
(0.011)\end{array}$ & $\begin{array}{c}0.006 \\
(0.011)\end{array}$ & $\begin{array}{c}0.007 \\
(0.008)\end{array}$ & $\begin{array}{c}0.007 \\
(0.008)\end{array}$ & $\begin{array}{r}-0.017 * \\
(0.010)\end{array}$ & $\begin{array}{c}-0.017 \\
(0.010)\end{array}$ & $\begin{array}{c}-0.014 \\
(0.011)\end{array}$ & $\begin{array}{c}-0.014 \\
(0.011)\end{array}$ \\
\hline Parental education: $12>$ years & $\begin{array}{c}0.017 \\
(0.014)\end{array}$ & $\begin{array}{c}0.017 \\
(0.014)\end{array}$ & $\begin{array}{c}-0.010 \\
(0.011)\end{array}$ & $\begin{array}{c}-0.010 \\
(0.011)\end{array}$ & $\begin{array}{c}0.006 \\
(0.008)\end{array}$ & $\begin{array}{c}0.006 \\
(0.008)\end{array}$ & $\begin{array}{c}-0.017 \\
(0.014)\end{array}$ & $\begin{array}{c}-0.017 \\
(0.014)\end{array}$ & $\begin{array}{c}-0.021 \\
(0.014)\end{array}$ & $\begin{array}{c}-0.022 \\
(0.014)\end{array}$ \\
\hline Parental education: missing & $\begin{array}{c}0.000 \\
(0.010)\end{array}$ & $\begin{array}{c}0.001 \\
(0.010)\end{array}$ & $\begin{array}{c}-0.002 \\
(0.012)\end{array}$ & $\begin{array}{c}-0.002 \\
(0.013)\end{array}$ & $\begin{array}{r}0.017 * \\
(0.010)\end{array}$ & $\begin{array}{c}0.016^{*} \\
(0.010)\end{array}$ & $\begin{array}{c}0.008 \\
(0.013)\end{array}$ & $\begin{array}{c}0.008 \\
(0.013)\end{array}$ & $\begin{array}{c}-0.001 \\
(0.012)\end{array}$ & $\begin{array}{c}-0.001 \\
(0.012)\end{array}$ \\
\hline \multicolumn{11}{|l|}{ Macro-level variables } \\
\hline GDP per capita PPP & $\begin{array}{c}-0.043 \\
(0.031)\end{array}$ & $\begin{array}{c}-0.043 \\
(0.031)\end{array}$ & $\begin{array}{l}0.037 * * \\
(0.019)\end{array}$ & $\begin{array}{l}0.037 * * \\
(0.019)\end{array}$ & $\begin{array}{c}0.005 \\
(0.016)\end{array}$ & $\begin{array}{c}0.005 \\
(0.016)\end{array}$ & $\begin{array}{c}0.024 \\
(0.015)\end{array}$ & $\begin{array}{c}0.024 \\
(0.015)\end{array}$ & $\begin{array}{r}-0.047 * \\
(0.025)\end{array}$ & $\begin{array}{r}-0.046^{*} \\
(0.024)\end{array}$ \\
\hline Socialist legacy & $\begin{array}{c}-0.165 * * \\
(0.069)\end{array}$ & $\begin{array}{l}-0.182 * * * \\
(0.069)\end{array}$ & $\begin{array}{c}0.083 \\
(0.051)\end{array}$ & $\begin{array}{c}0.074 \\
(0.052)\end{array}$ & $\begin{array}{c}0.020 \\
(0.048)\end{array}$ & $\begin{array}{c}0.041 \\
(0.046)\end{array}$ & $\begin{array}{l}0.146^{* * * *} \\
(0.048)\end{array}$ & $\begin{array}{l}0.153 * * * \\
(0.050)\end{array}$ & $\begin{array}{c}-0.072 \\
(0.054)\end{array}$ & $\begin{array}{c}-0.064 \\
(0.056)\end{array}$ \\
\hline \multicolumn{11}{|l|}{ Cross-level interactions } \\
\hline Strongly downward $\mathrm{x}$ socialist & - & $\begin{array}{c}0.073 \\
(0.050)\end{array}$ & - & $\begin{array}{l}0.067 * * \\
(0.031)\end{array}$ & - & $\begin{array}{c}-0.082 * * \\
(0.036)\end{array}$ & - & $\begin{array}{r}-0.045^{*} \\
(0.023)\end{array}$ & - & $\begin{array}{c}0.007 \\
(0.040)\end{array}$ \\
\hline Downward $\mathrm{x}$ socialist & - & $\begin{array}{c}0.017 \\
(0.019)\end{array}$ & - & $\begin{array}{c}0.023 \\
(0.026)\end{array}$ & - & $\begin{array}{c}-0.032 * * * \\
(0.010)\end{array}$ & - & $\begin{array}{c}-0.018 \\
(0.024)\end{array}$ & - & $\begin{array}{c}0.013 \\
(0.017)\end{array}$ \\
\hline Upward $\mathrm{x}$ socialist & - & $\begin{array}{c}0.023 \\
(0.019)\end{array}$ & - & $\begin{array}{c}0.002 \\
(0.015)\end{array}$ & - & $\begin{array}{c}-0.019 \\
(0.014)\end{array}$ & - & $\begin{array}{c}-0.002 \\
(0.019)\end{array}$ & - & $\begin{array}{c}-0.009 \\
(0.014)\end{array}$ \\
\hline Strongly upward x socialist & - & $\begin{array}{c}0.015 \\
(0.031)\end{array}$ & - & $\begin{array}{c}0.015 \\
(0.019)\end{array}$ & - & $\begin{array}{c}-0.033 * * \\
(0.014)\end{array}$ & - & $\begin{array}{c}-0.008 \\
(0.019)\end{array}$ & - & $\begin{array}{r}-0.050 * \\
(0.030)\end{array}$ \\
\hline Random intercept & $\begin{array}{l}0.097 * * * \\
(0.013)\end{array}$ & $\begin{array}{l}0.098 * * * \\
(0.013)\end{array}$ & $\begin{array}{l}0.088 * * * \\
(0.012)\end{array}$ & $\begin{array}{l}0.088 * * * \\
(0.012)\end{array}$ & $\begin{array}{l}0.075 * * * \\
(0.011)\end{array}$ & $\begin{array}{l}0.074 * * * \\
(0.011)\end{array}$ & $\begin{array}{l}0.057 * * * \\
(0.007)\end{array}$ & $\begin{array}{l}0.057 * * * \\
(0.007)\end{array}$ & $\begin{array}{l}0.627 * * * \\
(0.078)\end{array}$ & $\begin{array}{l}0.096 * * * \\
(0.015)\end{array}$ \\
\hline
\end{tabular}




\begin{tabular}{|c|c|c|c|c|c|c|c|c|c|c|}
\hline \multicolumn{11}{|l|}{ Statistics } \\
\hline AIC & $28,554.9$ & $28,557.5$ & $27,683.6$ & $27,685.9$ & $12,662.9$ & $12,658.7$ & $25,801.3$ & $25,805.5$ & $26,255.2$ & $26,255.6$ \\
\hline $\mathrm{BIC}$ & $28,770.8$ & $28,797.3$ & $27,899.3$ & $27,925.7$ & $12,878.7$ & $12,898.6$ & $26,017.1$ & $26,045.3$ & $26,471.1$ & $26,495.4$ \\
\hline Number of countries & 33 & 33 & 33 & 33 & 33 & 33 & 33 & 33 & 33 & 33 \\
\hline Number of observations & 21,895 & 21,895 & 21,895 & 21,895 & 21,895 & 21,895 & 21,895 & 21,895 & 21,895 & 21,895 \\
\hline
\end{tabular}

Notes: $* * * * *$, and $*$ denote statistical significance at the $0.01,0.05$, and 0.10 levels. Robust standard errors are in parentheses, weights applied.

Source: Author's calculations based on data from LITS (EBRD, 2010). 


\section{Appendix}

Figure A1. Bivariate associations between subjective social mobility and preferences on extra governmental spending in Western European and post-socialist societies.

(1) Western European societies

(2) Post-socialist societies
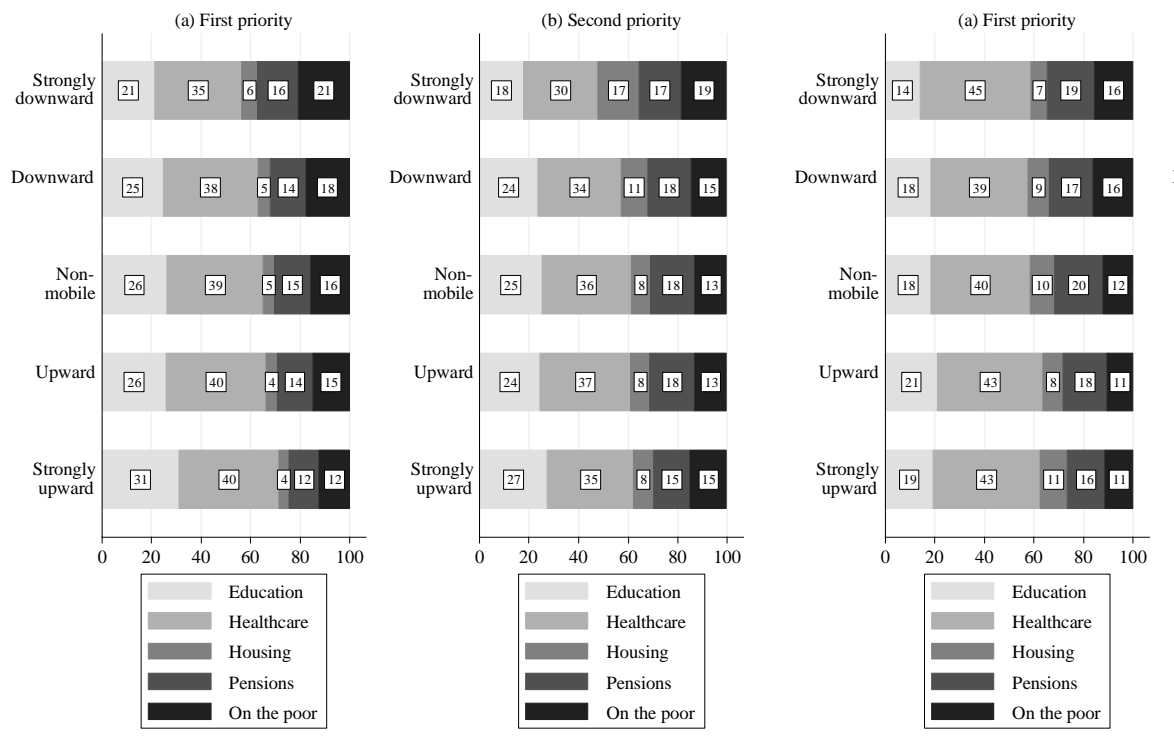

(b) Second priority

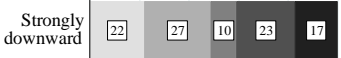

\begin{tabular}{l|lllll} 
Downward & 18 & 32 & 10 & 23 & 17
\end{tabular}

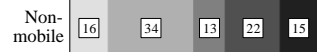

$\begin{array}{llllll}\text { Upward } & 20 \quad 33 \quad 12 & 21 & 13\end{array}$

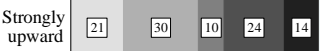

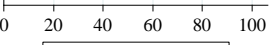

Education

Healthcare

Housing

Pensions

Pensions

Source: Author's calculations based on data from LITS (EBRD, 2010). 
Table A1. Descriptive statistics for independent variables used in analysis.

\begin{tabular}{|c|c|c|c|c|c|c|c|c|}
\hline & \multicolumn{4}{|c|}{ West European societies } & \multicolumn{4}{|c|}{ Post-socialist societies } \\
\hline & 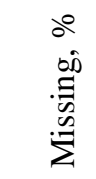 & 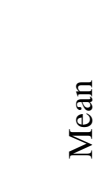 & $\hat{n}$ & 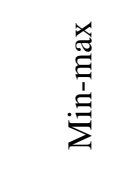 & 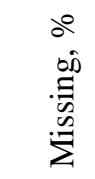 & $\stackrel{\Xi}{\stackrel{\Xi}{\Sigma}}$ & $\hat{s}$ & 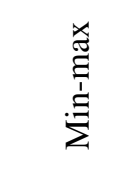 \\
\hline Male & 0.00 & 0.44 & 13.3 & $0-1$ & 0.00 & 0.38 & 0.48 & $0-1$ \\
\hline Age & 0.02 & 55.7 & 0.47 & $35-94$ & 0.06 & 0.48 & 54.8 & $35-99$ \\
\hline Married & 0.23 & 0.58 & 0.49 & $0-1$ & 0.60 & 0.65 & 0.48 & $0-1$ \\
\hline Urban settlement & 0.00 & 0.51 & 0.50 & $0-1$ & 0.00 & 0.44 & 0.50 & $0-1$ \\
\hline Rural settlement & 0.00 & 0.30 & 0.46 & $0-1$ & 0.00 & 0.43 & 0.49 & $0-1$ \\
\hline Respondents' education & 0.02 & 4.18 & 1.70 & $1-7$ & 0.01 & 4.06 & 1.45 & $1-7$ \\
\hline Socioeconomic ladder & 1.15 & 4.98 & 1.72 & $1-10$ & 1.64 & 4.17 & 1.67 & $1-10$ \\
\hline Mobility in ladder & 0.41 & -0.27 & 1.24 & $-8-8$ & 0.97 & -0.40 & 1.40 & $-9-8$ \\
\hline White collar occupation & 4.00 & 0.32 & 0.47 & $0-1$ & 0.73 & 0.21 & 0.41 & $0-1$ \\
\hline Blue collar occupation & 4.00 & 0.13 & 0.33 & $0-1$ & 0.73 & 0.12 & 0.33 & $0-1$ \\
\hline Farmers & 4.00 & 0.01 & 0.12 & $0-1$ & 0.73 & 0.04 & 0.20 & $0-1$ \\
\hline Unskilled service occupation & 4.00 & 0.05 & 0.21 & $0-1$ & 0.73 & 0.05 & 0.22 & $0-1$ \\
\hline Unemployed & 4.00 & 0.06 & 0.23 & $0-1$ & 0.73 & 0.10 & 0.30 & $0-1$ \\
\hline Retired & 4.00 & 0.33 & 0.47 & $0-1$ & 0.73 & 0.32 & 0.47 & $0-1$ \\
\hline Parental education: 6-11 years & 16.0 & 0.52 & 0.50 & $0-1$ & 23.0 & 0.37 & 0.48 & $0-1$ \\
\hline Parental education: $12>$ years & 16.0 & 0.20 & 0.40 & $0-1$ & 23.0 & 0.21 & 0.41 & $0-1$ \\
\hline
\end{tabular}
Source: Author's calculations based on data from LITS (EBRD, 2010). 